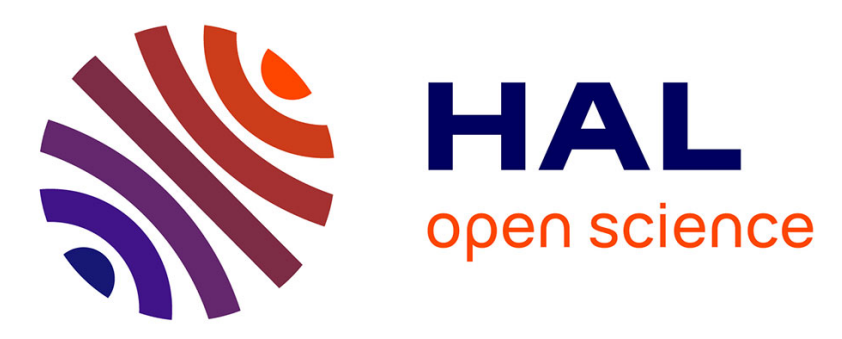

\title{
The user-centered design of an ambient technology for preventing falls at home
}

Marc-Eric Bobillier-Chaumon, Salima Body-Bekkadja, Florence Cros, Bruno Cuvillier

\section{- To cite this version:}

Marc-Eric Bobillier-Chaumon, Salima Body-Bekkadja, Florence Cros, Bruno Cuvillier. The usercentered design of an ambient technology for preventing falls at home. Gerontechnology, 2014, 13 (2), pp.169. 10.4017/gt.2014.13.02.090.00 . halshs-01561939

\section{HAL Id: halshs-01561939 \\ https://shs.hal.science/halshs-01561939}

Submitted on 26 Jul 2017

HAL is a multi-disciplinary open access archive for the deposit and dissemination of scientific research documents, whether they are published or not. The documents may come from teaching and research institutions in France or abroad, or from public or private research centers.
L'archive ouverte pluridisciplinaire HAL, est destinée au dépôt et à la diffusion de documents scientifiques de niveau recherche, publiés ou non, émanant des établissements d'enseignement et de recherche français ou étrangers, des laboratoires publics ou privés. 
Bobillier Chaumon, M.E., Bekkadja, S., Cros, F. \& Cuvillier, B. (2014). The user-centered design of an ambient technology for preventing falls at home. Gerontechnology, 13(2):169

doi: http://dx.doi.org/10.4017/gt.2014.13.02.090.00

M.E Bobillier CHAUMON, S. BEKKADJA, F. CROS, B. CUVILLIER. The user-centered design of an ambient technology for preventing falls at home. Gerontechnology 2014; 13(2):xxx; doi:10.4017/gt.2014.13.02.xxx.xx. Purpose In the context of the elderly homecare, an innovative and pervasive solution ${ }^{2}$, consisting of a camera and a microphone, is being conceptualized (ANR \& CNSA project). This system called CIRDO is based on an intelligent and systematic analysis of the audio and visual environment of the elderly. It could detect risk situations (falls) and therefore give the emergency alert. Method The design of the device is based on two levels of analysis. The first is to identify and characterize the falling process ${ }^{5}$ in order to provide system designers with a set of behavioral (key breaks) and verbal (keywords) descriptors (or indicators) required for setting up CIRDO. To do this, various methods have been deployed: semi -structured interviews with 65 aged people, analysis of daily life activities conducted at seniors homes, analysis and falls' script methods (simulation, filmed incidents observations and Personas method ${ }^{1}$ ). The second one was to explore the social acceptance of this new technology into the social systems of the elderly (composed by the person themselves, their family environment, professional and personal caregivers) by interviewing a sample of 62 people ( 24 elderly,19 family caregivers and 19 professional caregivers) through a process of triangulation methods (semi-structured interviews, focus groups and activity analyses). Results \& Discussion From the first set of data, 12 scripts of falls have been elaborated (Fig 1). In a second part, the social acceptance of the future device has been tackled, taking into account the experiences and positions of the various actors confronted to the device. The reading grid offered by Engeström's system of activity ${ }^{3}$ has shown an ambivalent positioning by these different actors: based on their experiences, their career and needs, each of them (elderly, professional counselors, family) has a different view of the object of their activity (support, help, care, prevention, control), and therefore has specific expectations and fears. The function and purpose of the device are (implicitly) heterogeneous because interpreted differently by the various stakeholders (Fig 2): visions that may be incomplete, conflicting or partially contradictory. The difficulty in the design and implementation of CIRDO is to adjust to a psycho-socio, home embedded system that is different every time given (i) the diversity of activities at risk of the elderly, and (ii) the interests of different actors.

\section{References}

1. Brangier, E. \& Bornet, C. Persona: A method to produce representations focused on consumers' needs. In W. Karwowski, M. Soares \& N. Stanton (Eds). Human Factors and Ergonomics in Consumer Product Design. Taylor and Francis ; 2011. 38-61

2. Buiza, C., Soldatos, J., Petsatodis, T., Geven, A. \& Etxaniz, A. HERMES : Pervasive Computing and Cognitive Training for Ageing Well. LCNS, 5518 ; 2009. 756-763.

3. Engeström, Y. Learning by expanding : an activity-theoretical approach to developmental research. Helsinky, Orienta-Konsultit. 1987.

4. Rowe, J. Fall prevention: Core characteristics and practical interventions. Home Health Care Managment Practice, 2010 ; 23 (1) : 20-26.

Keywords: Pervasive technology, Acceptance, Domestic activity, Elderly people

Address: GRepS, Université Lyon 2, Lyon France

E: marc-eric.bobillier-chaumon@univ-lyon2.fr

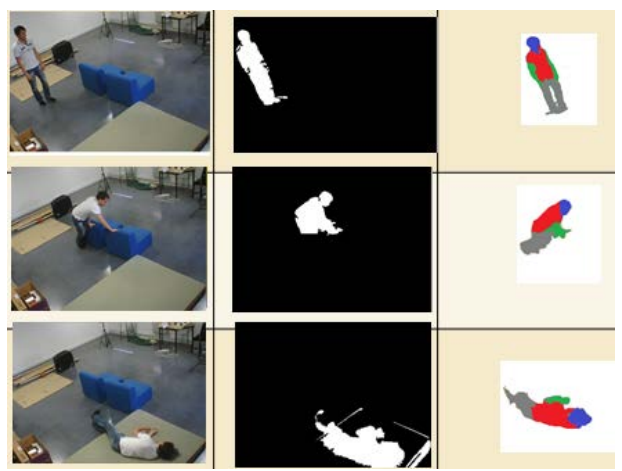

Fig 1. Sample Script of a fall used to set CIRDO

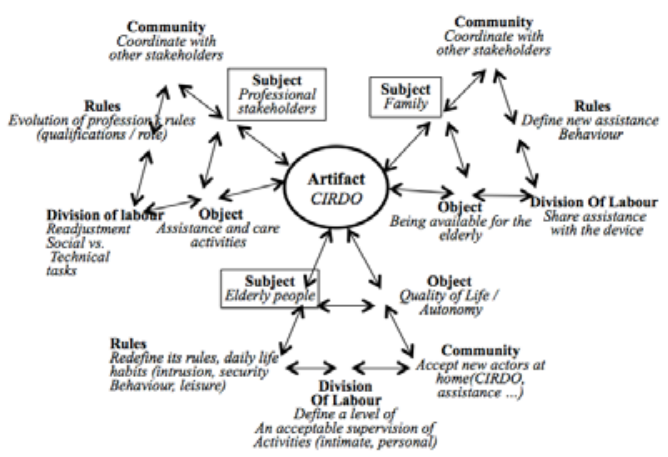

Fig 2. Articulation between the Systems of activity of actors in the home 
Bobillier Chaumon, M.E., Bekkadja, S., Cros, F. \& Cuvillier, B. (2014). The user-centered design of an ambient technology for preventing falls at home. Gerontechnology, 13(2):169 doi: http://dx.doi.org/10.4017/gt.2014.13.02.090.00 